\title{
National Judicial Policy for Inclusive and Accessible Labor Justice: Permanent Programs and Actions Aimed at the Inclusion and Accessibility of People with Disabilities at Work
}

\author{
Déa Marisa Brandão Cubel Yule* \\ Strictu Senso Graduate Program in Conflict Resolution System, UNLZ- Argentina \\ Rua Jornalista Belizário Lima, 418, CEP 79004-915, Campo Grande - MS, Brazil
}

\begin{abstract}
The present study aimed to discuss the importance of implementing an inclusive and accessible national judicial policy, which promotes essential practices and actions to bring about cultural change rooted in society, through a deductive-descriptive method and with legislative, bibliographic, documentary and empirical research. , it was intended to demonstrate the importance of a National Judicial Policy that aims to develop, on a permanent basis, programs and actions aimed at promoting the inclusion and accessibility of people with disabilities in the world of work and promoting inclusive Justice. People with disabilities continue to face barriers to their effective participation as equal members of society, as well as to face violations of their human rights. These rules say what to do, but they do not say how to do it. There is no sustainable world if it is not accessible, if it is not inclusive, and the Labor Court has moral authority capable of influencing and transforming the culture of Brazilian society, through the implementation of programs and actions. Moral authority is attitude. Legislation allows this and society expects this from the Judiciary. This is the answer that can be given through a National Judicial Policy of Inclusive and Accessible Justice, acting effectively to fulfill the objectives established through the UN Agenda 2030.
\end{abstract}

Keywords: Accessibility. Inclusion. National Legal Policy.

DOI: $10.7176 /$ RHSS/11-12-05

Publication date:June $30^{\text {th }} 2021$

\section{Introduction}

This paper aimed to discuss the importance of implementing an inclusive and accessible national legal policy that promotes essential practices and actions to bring about ingrained cultural change in society.

Almost $24 \%$ of the Brazilian population is made up of people who have some type of disability and only $1 \%$ are in the labor market, despite broad national and international legislation on the topic of inclusion and accessibility.

These norms deal with the "should-bes", what should be done, and it is believed that with a National Legal Policy it will be possible to collaborate in indicating the way of the effective implementation of these Rights of the Person with Disabilities, taking them out of the legal field and bringing them to the factual field of concreteness.

Through a deductive-descriptive method and with legislative, bibliographic, documentary, and empirical research, the article intends to demonstrate the benefits of a National Legal Policy with the objective of permanently developing programs and actions aimed at promoting the inclusion and accessibility of the person with disabilities in the world of work and promoting inclusive justice.

2. Inclusion and accessibility of people with disabilities: implementation, national legal policy from the 5th wave of access to justice

In the international and domestic legal system, there is a wide range of legislations dealing with the rights of people with disabilities. At an international level, the Federative Republic of Brazil, as a State Party to the International Convention on the Rights of Persons with Disabilities (Note ${ }^{1}$ ) (ratified with the equivalence of a constitutional amendment in 2008), recognized the importance of the World Program of Action for Persons with Disabilities, to influence the promotion of policies, programs and actions at national, as well as regional and international levels, to enable greater equal opportunities for people with disabilities.

From the aforementioned Convention, a commitment was made to adopt effective and appropriate measures to raise the awareness of society as a whole about the rights, capabilities, and contributions of people with disabilities, fighting prejudice through public awareness campaigns.

At an international level, the UN 2030 Agenda (Note ${ }^{2}$ ), also signed by the Brazilian State, established, along with other nations that integrate it, objectives for promoting inclusive and sustainable economic growth

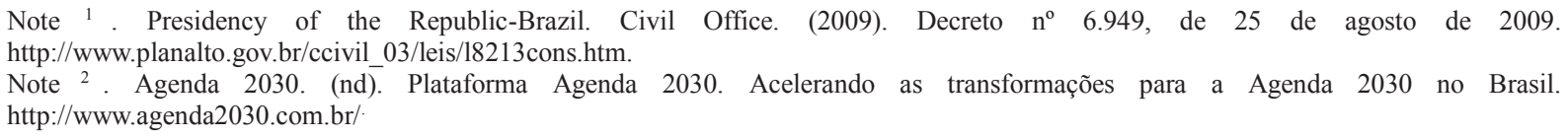


and the promotion of inclusive societies, providing access to justice for all and building effective, accountable, and inclusive institutions at all levels.

In this 2030 agenda, (Note ${ }^{1}$ ) the essential role is recognized, not only of national parliaments and governments, but also of public institutions (among them, the Labor Justice), where everyone will work in close collaboration with regional and local authorities, subregional institutions, international institutions, academia, philanthropic organizations, and groups of volunteers in implementing these objectives. It is, without a doubt, an inclusive policy, with the participation of the whole society and the Public Authority as a whole. At a national level, the achievement of the dignity of people with disabilities is the foundation of the Democratic Rule of Law (art. 1, III and IV, of the Brazilian Constitution) and there is no dignity where there is no guarantee of equal opportunities for people with disabilities.

We also have the Brazilian Inclusion Law (Law 13.146/2015) which establishes that people with disabilities have the right to work of free choice and acceptance, in an accessible and inclusive environment, on equal terms with other people (Art. 34), being the primary purpose of public labor and employment policies to promote and guarantee conditions of access and permanence for people with disabilities in the field of work (Art. 35).

Despite international and national standards, people with disabilities continue to face impediments to their effective participation as equal members of society, as well as violations of their human rights.

In Brazil, according to the census of the Brazilian Institute of Geography and Statistics - IBGE 2010², almost $24 \%$ of the Brazilian population is comprised of people who have some kind of disability and only $1 \%$ of these 45 million people are in the labor market. These figures show us that there are still gigantic barriers for people with disabilities to enter and remain in employment, ranging from access to education and professional qualification, architectural and urbanistic, transportation, communication, technological and attitudinal barriers.

Despite international and national standards, people with disabilities continue to face impediments to their effective participation as equal members of society, as well as violations of their human rights. Only $1 \%$ have work.

It is believed that the answer and the pathway of how Brazil can be inclusive and accessible, can be given through a National Legal Policy of inclusive and accessible justice. Legislation provides legal support for this action and there is no need to talk about access to Justice if Justice is not accessible to people with disabilities.

This transformation came about in the international and national legal systems, with the International Convention on the Rights of Persons with Disabilities and its Optional Protocol, signed in New York, on March 30, 2007, and approved by the National Congress, through the Legislative Decree number 186, of July 9, 2008, according to the procedure of Paragraph 3 of Art. 5 of the Constitution (Constitutional Amendment) and its enactment through Decree number 6.949, of August 25, $2009^{34}$.

Said Convention dealt explicitly with Access to Justice for persons with disabilities, in Article 13, items 1 and 2 :

1. States Parties shall ensure that persons with disabilities have effective access to justice, on an equal basis with others, including through the provision of age-appropriate procedural adaptations, in order to facilitate the effective role of persons with disabilities as direct or indirect participants, including as witnesses, in all legal proceedings, such as investigations and other preliminary stages.

2.In order to ensure that persons with disabilities have effective access to justice, States Parties shall promote the appropriate training of those working in the field of administration of justice, including the police and prison system officials. (Emphasis added)

After that, a major normative transformation took place, in 2015, when the Brazilian Law for the Inclusion of Persons with Disabilities - also known as the Statute for Persons with Disabilities - was enacted (Law 13.146, of July 6, 2015) (Note ${ }^{5}$ ).

This Statute went beyond the International Convention, dedicating Title I of Book II (special part) to address Access to Justice and, then, in a clear and articulated way, dealt not only with guaranteeing access to jurisdictions, but also with the guarantee of accessibility, through adaptations and assistive technology resources available as well as to lawyers, public defenders, magistrates or members of the Public Ministry (Art. 80) (Note ${ }^{6}$ ) and also established priority assistance in procedural protocols and judicial and

Note ${ }^{1}$. Agenda 2030. (nd). Plataforma Agenda 2030. Acelerando as transformações para a Agenda 2030 no Brasil. http://www.agenda2030.com.br/.

Note $^{2}$. 2010 Census (nd). Brazilian Institute of Geography and Statistics - IBGE. https://censo2010.ibge.gov.br/.

Note $^{3}$. Presidency of the Republic-Brazil. General secretary. (July 24, 2015). Lei n ${ }^{\mathrm{o}} 13.146$. http://www.planalto.gov.br/ccivil_03/ ato20152018/2015/lei/113146.htm.

Note $^{4}$. O Governo brasileiro depositou o instrumento de ratificação dos referidos atos junto ao Secretário-Geral das Nações Unidas em $1^{\circ}$ de agosto de 2008. http://www.planalto.gov.br/ccivil 03/ ato2007-2010/2009/decreto/d6949.

Note $^{5}$. Presidency of the Republic-Brazil. General secretary. (July 24, 2015). Lei n ${ }^{\circ}$ 13.146. http://www.planalto.gov.br/ccivil_03/_ato20152018/2015/lei/113146.htm.

Note $^{6}$. Presidency of the Republic-Brazil. General secretary. (July 24, 2015). Lei $\mathrm{n}^{\circ}$ 13.146. http://www.planalto.gov.br/ccivil 03/ ato20152018/2015/lei/113146.htm. 
administrative procedures in which the disabled person is a party or an interested party (Art. 9) (Note ${ }^{1}$ ).

An important rule of guarantee of Access to Justice was also issued by the National Justice Council (Resolution CNJ 230, of July 22, 2016) $\left(\right.$ Note $^{2}$ ), whose purpose is to guide the adequacy of the activities of the entities of the Judiciary and their auxiliary services in regarding the determinations made by the International Convention on the Rights of Persons with Disabilities and its Optional Protocol (enacted through Decree number $6.949 / 2009\left(\right.$ Note $\left.^{3}\right)$ ) and by the Brazilian Law for the Inclusion of Persons with Disabilities (Law number 13.146/2015) $\left(\right.$ Note $\left.^{4}\right)$.

The Superior Council for Labor Justice (CSJT), in turn, in a Judgment Session, on October 25, 2019, approved the National Legal Policy for inclusion and accessibility of people with disabilities at work and for Inclusive Justice, with the regulatory procedure of this inclusive Policy still being processed.

It is undeniable, therefore, to be faced with a new wave of conceptual transformation of access to justice, in which, in order to guarantee this right, it is essential that this access be open, without barriers that prevent users and operators of the Law with disabilities the exercise of rights and professional performance, with full autonomy, within the scope of the Judiciary Branch (Note ${ }^{5}$ ).

One can exemplify what characterizes a global action of inclusion and accessibility, pointing to a concrete action, within a National Legal Policy, in the context of the pandemic by COVID-19. On March 11, 2020, the World Health Organization - WHO, issued a public announcement of a pandemic regarding the new Coronavirus. Through Legislative Decree number 6, of March 20, 2020 (Note ${ }^{6}$ ), the National Congress recognized the state of public calamity in Brazil. In view of this exceptional and emergency situation, the need arose to nationally standardize the functioning of the Judiciary Branch, and thus Resolutions 313 ((Note ${ }^{7}$ ), 314 (Note ${ }^{8}$ ), 318 (Note ${ }^{9}$ ) and $322\left(\right.$ Note $^{10}$ ) were edited by the National Justice Council (CNJ) in 2020. The first Resolution 313 (of March 19, 2020) suspended the on-site workday and left the discipline of the remote work of magistrates and public servants to the courts. Afterward, the CNJ issued Ordinance 61, of March 31, 2020 (Note ${ }^{11}$ ), instituting an emergency videoconference platform to hold judicial hearings and trial sessions of the Courts, during the period of social distancing.

The Cisco Webex videoconferencing platform was made available by the CNJ to the entire Brazilian Judiciary Branch and recommended as the preferred platform for hearings and court sessions (Resolution 314). Within this context, access to the emergency platform used for remote hearings and its domain has become a necessity for the operator of the Brazilian legal system, a member of the Judiciary Branch and of the institutions which are essential to the jurisdictional function.

The Superior Council for Labor Justice (CSJT), with the support of the Permanent Accessibility and Inclusion Commission of the TRT (Regional Labor Court) of the 24th Region, developed a free training program entitled "Accessible Remote Hearing", aimed at public servants and magistrates from all of the Brazilian Judiciary Branch, lawyers and Law students who are blind or have low vision.

The program focuses on promoting the inclusion and accessibility of people with disabilities in the electronic legal system, in times of a Pandemic, and is relevant because 528,624 people with visual impairments live in Brazil.

The program sought to ensure the effective performance of the Labor Justice in order to fulfill objective 16 of the UN 2030 Agenda (Note ${ }^{12}$ ), also signed by the Brazilian State, of "promoting peaceful and inclusive societies for sustainable development, providing access to justice for all and building effective, accountable and inclusive institutions at all levels".

It is a pioneering program in Brazilian Justice, of extreme relevance and social impact, whose objective is to

Note $^{1}$. Presidency of the Republic-Brazil. General secretary. (July 24, 2015). Lei n ${ }^{\circ}$ 13.146. http://www.planalto.gov.br/ccivil_03/ato20152018/2015/lei/113146.htm.

Note $^{2}$. Presidency of the Republic-Brazil. Resolução No 230 (22 jun. 2016). DJe/CNJ, n 106. https://atos.cnj.jus.br/atos/detalhar/2301 Accessed on August 18, 2020.

Note: ${ }^{3}$. Presidency of the Republic-Brazil. Civil Office. Deputy Director for Legal Affairs. (25 Aug. 2009). Decreto $\mathrm{n}^{\circ} 6.949$. http://www.planalto.gov.br/ccivil 03/ ato2007-2010/2009/decreto/d6949.htm.

Note: ${ }^{4}$. Presidency of the Republic-Brazil. General Secretary. Deputy Director for Legal Affairs. (July 6, 2015). Lei $\mathrm{n}^{0} 13.146$. http://www.planalto.gov.br/ccivil_03/_ato2015-2018/2015/lei/113146.htm.

Note: ${ }^{5}$. Yule, Déa Marisa B. Cubel. (2020) Teoria geral dos sistemas e discriminação da pessoa com deficiência. Correlação. Sistema sociocultural. Crescimento econômico sustentável e instituições eficazes: Quinta onda de acesso à justiça. Revista do Tribunal Regional do Trabalho da 24 Região (5; 75-88). http://www.trt24.jus.br/documents/1314207/4379560/Revista+2020 2.pdf/65ea2212-3522-4f6b-8774$660311 \mathrm{~d} 47 \mathrm{de} 3$

Note: ${ }^{6}$. Federal Senate. (2020) Decreto legislativo $\mathrm{n}^{\circ}$ 6. http://www.planalto.gov.br/ccivil 03/portaria/DLG6-2020.htm.

Note: ${ }^{7}$ Presidency of the Republic-Brazil. (03.19.2020). Resolução No 313. DJe/CNJ n ${ }^{0}$ 71/2020. https://atos.cnj.jus.br/atos/detalhar/3249.

Note: ${ }^{8}$. Presidency of the Republic-Brazil. (04.20.2020). Resolução No 314 . DJe/CNJ no 106/2020. https://atos.cnj.jus.br/atos/detalhar/3283.

Note: ${ }^{9}$. Presidency of the Republic-Brazil. (05.07.2020). Resolução No 318. DJe/CNJ no 131/2020. https://atos.cnj.jus.br/atos/detalhar/3308.

Note: ${ }^{10}$. Presidency of the Republic-Brazil. (06.01.2020). Resolução No 322. DJe/CNJ no 164/2020. https://atos.cnj.jus.br/atos/detalhar/3333.

Note: ${ }^{11}$. Presidency of the Republic-Brazil. (03.19.2020). Portaria $\mathrm{N}^{\circ}$ 61. DJe/CNJ n ${ }^{\circ} 91 / 2020$. https://atos.cnj.jus.br/atos/detalhar/3266.

Note: ${ }^{12}$. Agenda 2030. (nd). Plataforma Agenda 2030. Acelerando as transformações para a Agenda 2030 no Brasil. https://nacoesunidas.org/pos2015/agenda2030/. 
present blind and low vision law operators and law students to the remote hearing platform and its tools, and to guide them as to how to use it in an accessible way.

The training aims to enable law operators, blind or with low vision, to autonomously develop the main routines which are necessary for the performance of these professionals' activities, in the remote hearing environment. The program is unfolding and is preparing for new classes, aimed at people with hearing impairment. In Brazil, there are 1,798,967 people with hearing impairment.

Only by mastering the remote hearing platform in an accessible way will there be an effective breach of the technological and communicational barrier, thus ensuring that the person with disabilities has autonomy and protagonism in their professional trajectory in the legal world.

A trajectory of growth and protagonism is only possible when we move towards a process of self-realization and socialization, which, according to Jubram (2017) ( Note ${ }^{1}$ ),

[...] undoubtedly encompasses cooperation and concern for the common good. It is autonomy (both moral and intellectual) that also frees us from social conditions, allowing us to make choices, both in our personal and professional life, in harmony with our deepest self.

The purpose of the national action and program "Accessible Remote Hearing" was to be an instrument of effective access to justice and acted concretely to implement the "should-bes" brought by international and national legislation related to the Rights of Persons with Disabilities, guaranteeing the person with disabilities protagonism in the performance of jurisdictional and legal activities, providing tools that break technological, communication and attitudinal barriers, guaranteeing the person with disabilities the autonomy necessary for their professional accomplishment, making them the protagonist of the work they perform in the Brazilian courts.

\section{Conclusion}

The present article believes in the importance of the performance of the Labor Justice in a national legal policy, which establishes programs and actions aimed at the realization of the rights of the person with disabilities, as an agent to promote a cultural change rooted in society.

There is no sustainable world if it is not accessible nor inclusive, and the Labor Justice has moral authority capable of influencing and transforming the culture of our society, through the implementation of programs and actions. Authority is attitude. Legislation allows this and society expects this from the Judicial Branch.

\section{References}

Agenda 2030. (nd). Plataforma Agenda 2030. Acelerando as transformações para a Agenda 2030 no Brasil. http://www.agenda2030.com.br/.

Census 2010 (nd). Brazilian Institute of Geography and Statistics - IBGE. https://censo2010.ibge.gov.br/.

Federal Senate. (2020). Decreto legislativo no 6. http://www.planalto.gov.br/ccivil 03/portaria/DLG6-2020.htm.

Jubram, Renata. (2017). Autonomia, Resiliência e Protagonismo: provocações reflexivas para desenvolver competências. Integrare.

Presidency of the Republic-Brazil. (03.19.2020). Portaria $\mathrm{N}^{\mathrm{o}}$ 61. DJe/CNJ $\mathrm{n}^{\mathrm{o}}$ 91/2020. https://atos.cnj.jus.br/atos/detalhar/3266.

Presidency of the Republic-Brazil. (03.19.2020). Resolução $\mathrm{N}^{\mathrm{o}}$ 313. DJe/CNJ $\mathrm{n}^{\circ} \quad 71 / 2020$. https://atos.cnj.jus.br/atos/detalhar/3249.

Presidency of the Republic-Brazil. (05.07.2020). Resolução N N 318 . DJe/CNJ $\mathrm{n}^{\circ} \quad 131 / 2020$. https://atos.cnj.jus.br/atos/detalhar/3308.

Presidency of the Republic-Brazil. (06.01.2020). Resolução No 322. DJe/CNJ $\mathrm{n}^{0} \quad 164 / 2020$. https://atos.cnj.jus.br/atos/detalhar/3333.

Presidency of the Republic-Brazil. 04.20.2020). Resolução $\mathrm{N}^{\mathrm{o}} \quad 314 . \quad \mathrm{DJe} / \mathrm{CNJ} \quad \mathrm{n}^{\mathrm{o}} \quad 106 / 2020$. https://atos.cnj.jus.br/atos/detalhar/3283.

Presidency of the Republic-Brazil. Civil Office. (25 August, 2009). Decreto $\mathrm{n}^{0} \quad 6.949$. http://www.planalto.gov.br/ccivil_03/leis/18213cons.htm.

Presidency of the Republic-Brazil. Civil Office. Deputy Director for Legal Affairs. (25 August, 2009). Decreto $n^{0}$ 6.949. http://www.planalto.gov.br/ccivil_03/_ato2007-2010/2009/decreto/d6949.htm.

Presidency of the Republic-Brazil. General Secretary. (24 July, 2015). Lei $\mathrm{n}^{0} 13.146$. http://www.planalto.gov.br/ccivil_03/_ato2015-2018/2015/lei/113146.htm.

Presidency of the Republic-Brazil. General Secretary. Deputy Director for Legal Affairs. (06 July, 2015). Lei $\mathrm{n}^{\circ}$ 13.146. http://www.planalto.gov.br/ccivil_03/_ato2015-2018/2015/lei/113146.htm.

Note: 22. JUBRAM, Renata. (2017). Autonomia, Resiliência e Protagonismo: provocações reflexivas para desenvolver competências. Integrare. 
Presidency of the Republic-Brazil. Resolução No $230 \quad$ (22 June, 2016). DJe/CNJ, n $^{\circ} 106$. https://atos.cnj.jus.br/atos/detalhar/2301 Accessed on 18 August, 2020.

Yule, Déa Marisa B. Cubel. (2020). Teoria geral dos sistemas e discriminação da pessoa com deficiência. Correlação. Sistema sociocultural. Crescimento econômico sustentável e instituições eficazes: Quinta onda de acesso à justiça. Revista do Tribunal Regional do Trabalho da 24 Região (5; 75-88). http://www.trt24.jus.br/documents/1314207/4379560/Revista+2020_2.pdf/65ea2212-3522-4f6b-8774$660311 \mathrm{~d} 47 \mathrm{de} 3$. 